\title{
ENVIRONMENTAL STRESS: USAHA MENGATASI STRESS YANG BERSUMBER DARI LINGKUNGAN
}

\author{
Antonius Atosökhi Gea \\ Jurusan Psikologi, Fakultas Psikologi, Bina Nusantara University \\ Jl. Kemanggisan Ilir III No. 45. Kemanggisan, Palmerah Jakarta Barat 11480 \\ antoniusgea@binus.edu
}

\begin{abstract}
There are times where human relationships with the surrounding environment takes place in a state of balance, so as not to cause pressure against him for human life. But there is also time to balance the relationship is disturbed by various events that often exceed the limits of human adaptability. This last condition arises either by events beyond human control, such as natural disasters or events that arise as a result of human engagement itself, such as over-exploitation of nature and creation of various technology products. The events that happened outside the human self has become a source of stress, which is sometimes understood as external conditions that suppress human adaptation and demanding, and sometimes also understood as a human response to external conditions, which showed special signs, either on the physical, psychological as well as on the visible behavior. Faced with the events that potentially lead to stress, humans need to do assessments leading to a positive attitude toward the stimulus. In addition it should also be developed in ways that help to achieve the adaptation that produces a good balance and lower levels of stress itself. Better anticipation can also be reached in which humans make important changes, mainly related to the views and treatment of the natural environment, and attitudes in developing and utilizing technology, especially related to the negative impacts caused.
\end{abstract}

Keywords: stress, response, adaptation, environment, technology

\begin{abstract}
ABSTRAK
Ada saatnya dimana hubungan manusia dengan lingkungan sekitarnya berlangsung dalam keadaan seimbang, sehingga tidak menimbulkan tekanan yang memberatkan bagi kehidupan manusia. Tetapi ada saatnya juga hubungan keseimbangan ini terganggu oleh berbagai kejadian yang sering melampaui batas kemampuan adaptasi manusia. Kondisi terakhir ini timbul baik oleh kejadian yang berada di luar kontrol manusia, seperti bencana alam maupun kejadian yang timbul sebagai akibat dari keterlibatan manusia sendiri, seperti eksploitasi berlebihan terhadap alam dan penciptaan berbagai produk teknologi. Kejadian-kejadian yang terjadi di luar diri manusia itu telah menjadi sumber terjadinya stress, yang kadang dimengerti sebagai kondisi luar yang menekan dan menuntut adaptasi manusia, dan kadang juga dimengerti sebagai respons manusia terhadap kondisi dari luar itu, yang memperlihatkan tanda-tanda khusus, baik pada aspek fisik, kejiwaan maupun pada perilaku yang kelihatan. Menghadapi kejadian-kejadian yang berpotensi menimbulkan stress itu, manusia perlu melakukan penilaian yang mendorong munculnya sikap positif terhadap stimulus itu. Selain itu perlu juga dikembangkan cara-cara yang membantu tercapainya adaptasi yang menghasilkan keseimbangan yang baik dan menurunkan tingkat stress itu sendiri. Antisipasi yang lebih baik bisa juga ditempuh dimana manusia mengadakan perubahan penting, terutama terkait pandangan dan perlakuannya terhadap alam lingkungannya, serta sikap dalam mengembangkan dan memanfaatkan teknologi, khususnya berkaitan dengan dampak-dampak negatif yang ditimbulkannya.
\end{abstract}

Kata kunci: stres, respon, adaptasi, lingkungan, teknologi 


\section{PENDAHULUAN}

Umum diakui bahwa manusia memiliki kemampuan adaptasi yang tinggi terhadap lingkungan dimana dia tinggal dan berada. Kalau dilihat dari pola hubungan manusia dengan alam lingkungannya, dapat dikatakan bahwa pada awalnya manusia lebih banyak menyesuaikan diri dengan lingkungan. Dalam bercocok tanam umpamanya, manusia menyesuaikan diri dengan musim. Demikian juga dalam hal beternak, manusia menyesuaikan diri dengan ketersediaan makanan bagi ternak berupa rumput atau tumbuh-tumbuhan. Mereka siap berpindah-pindah mengikuti tempat dimana makanan tersedia untuk ternak mereka. Demikianlah dalam banyak hal manusia lebih banyak menyesuyaikan diri dengan alam lingkungannya. Dalam situasi seperti ini manusia dan alam mengalami hubungan yang harmonis, seimbang dan selaras. Semua bisa hidup dalam suasana saling mendukung.

Dalam perkembangan kemudian, masnusia, dengan kemampuan berpikirnya, mulai merubah lingkungannya, menciptakan hal-hal baru, menyesuaikannya dengan kebutuhan dan keinginannya (Raven, 1995). Demikianlah manusia mulai menciptakan berbagai peralatan yang diperlukan untuk memampukannya mengolah dan mengendalikan lingkungannya dengan tujuan menghasilkan berbagai kemudahan bagi hidupnya. Manusia mengembangkan terus kemampuan teknologinya untuk bisa memproduksi berbagai peralatan yang berfungsi memperpanjang dan memperkuat kemampuan anggota tubuhnya, yang membuatnya mampu melakukan hal-hal yang sebelumnya hanya bisa dilakukannya secara sangat terbatas.

Untuk memperpanjang kemampuannya berjalan, dia mencitakan alat-alat transportasi, mulai dari yang sederhana hingga yang paling dan semakin canggih, baik untuk transportasi di darat, di laut maupun di udara. Untuk menambah kemampuan tangannya bekerja dia menciptakan berbagai peralatan mesin-mesin yang memiliki kemampuan yang tidak terbayangkan sebelumnya. Untuk memperpanjang kemampuan penglihatannya, dia menciptakan video, televisi, teropong, dan alat bantu lihat yang semakin canggih. Untuk menambah kemampuan mendengarnya, dia menciptakan radio, telepon, dan alat bantu dengar lainnya. Untuk menambah kemampuan otaknya mengolah data dan fungsi-fungsi informasi lainnya, diciptakannya komputer. Demikianlah beberapa contoh dimana manusia dengan kemampuan istimewanya mencipatakan hal-hal yang baru, untuk mengendalikan alam lingkungannya sesuai dengan kebutuhan bahkan untuk kenyamanan dan kesenangannya.

Namun kemudian, campur tangan manusia yang berlebihan terhadap alam, yang membuat lingkungan mengalami perubahan besar, manusia balik menerima tantangan dari lingkungannya, yang mana tantangan itu menggugah kemampuan adaptasi manusia. Muncullah berbagai hal seperti tindakan kriminalitas, perang, terorisme, dan pemusnahan sesama manusia yang didukung oleh kepemilikan peralatan yang ada. Juga meluas terjadinya malapetaka alamiah, seperti bencana kelaparan, banjir, kekeringan, gempa bumi, dan letusan gunung berapi. Demikian juga meluas bahaya dari teknologi yang dikembangkan oleh manusia, seperti bisingnya bunyi kendaraan dan mesin-mesin, semakin banyaknya pesawat udara yang menggunakan lintasan udara yang sama, semakin banyaknya penumpukan bahan-bahan kimia dan penyebaran radiasi nuklir, dan sebagainya. Semuanya ini menguji tapal batas kemampuan adaptasi manusia.

Pengembangan teknologi dan tindakan merubah lingkungan sesuai keinginannya, manusia di satu sisi telah berhasil memajukan peradabannya, namun di sisi lain juga secara tak langsung telah menciptakan bencana bagi dirinya sendiri. Pencemaran udara dan air tanah, kebisingan yang memekakkan telinga, penggunaan energi yang semakin tak terkendali, beban kerja keras dan mobilitas kehidupan yang semakin cepat, merupakan wujud-wujud dari tekanan yang dihadapi manusia. Hari demi hari, manusia, selain menikmati kesenangan sebagai hasil dari pengendalian dan pengelolaan lingkungannya, juga semakin menghadapi berbagai tantangan, khususnya untuk bisa beradaptasi dengan kondisi yang terus berubah. Hal ini telah mendorong manusia untuk secara genius menciptakan proteksi bagi dirinya dengan semakin berjuang untuk mengelola dan menguasai 
lingkungannya, memiliki materi dan bebagai bahan dan peralatan yang membuatnya merasa semakin nyaman. Namun dalam kenyataannya rasa nyaman itu terusik oleh kejadian-kejadian yang ditimbulkan oleh pemenuhan rasa nyaman itu sendiri. Berbagai tekanan yang tak terhindarkan yang berasal dari lingkungan telah memicu apa yang disebut dengan stres, beban berat yang menekan jiwa dan badan manusia. Terjadi sesuatu yang ironi, dimana dalam usaha-usaha manusia mengolah dan menguasai bumi untuk memenuhi kebutuhan dan keinginannya, manusia sekaligus mengurangi kemampuan bumi yang secara terus menerus menyediakan segala yang dibutuhkan oleh seluruh umat manusia (Postel, 1994).

\section{HASIL DAN PEMBAHASAN}

\section{Environmental Stress dan Penyebabnya}

Pertanyaan sekarang adalah: apa yang dimaksud dengan stres disini, apakah tuntutan lingkungan itu sendiri atau respon seseorang terhadap tuntutan itu? Gejala yang bisa diamati adalah bahwa tuntutan dari luar itu telah mengakibatkan tekanan bagi manusia, yang membuat kecemasannya semakin meningkat. Tekanan berat dari lingkungan, seperi kebisingan yang melebih ambang batas, konsentrasi karbondioksida melebihi batas toleransi, atau ketika penghuni dunia ini terlalu banyak, telah membawa dampak-dampak yang memberatkan bagi manusia.

Dari apa yang dikemukakan di atas dapat disimpulkan bahwa stres adalah suatu keadaan yang muncul ketika orang berhadapan dengan tuntutan dari lingkungannya yang memintanya untuk berusaha menyesuaikan diri sesuai dengan tuntutan yang ada. Dapat dikatakan umumnya para peneliti setuju dengan pengertian ini. Tapi hal yang masih belum ada kesepakatan adalah persoalaan apakah stres itu merupakan tuntutan dari luar atau respon yang diberikan terhadap tuntutan itu (Veitch \& Arkkelin, 1995).

Beberapa teori mendukung pemahaman tentang sters sebagai respon yang diberikan oleh manusia terhadap keadaan dari luar. Stres harus dimengerti sebagai sejumlah perubahan yang muncul dari berbagai reaksi intensif yang diperlihatkan oleh seseorang. Tanda-tanda respons ini meliputi indikator yang kelihatan secara fisik seperti denyut jantung bertambah cepat, tekanan darah naik, serta tanda-tanda kejiwaan seperti gelisah, kehilangan kontrol diri, dan perasaan tidak nyaman. Pada saat sedang menghadapi stres gejala-gejala itu muncul melebihi suasana ketika orang sedang menunggu masuk kamar operasi untuk suatu tindakan pembedahan.

Catatan penting yang perlu dikemukakan terkait pemahaman seperti ini adalah kondisi-kondisi (respons) seperti disebutkan di atas dapat terjadi sebagai akibat dari penyebab (stimulus) yang berbeda. Umpamanya, denyutan jantung bisa saja meningkat sebagai akibat dari latihan fisik, atau karena melihat film horor, mengendarai roller coaster, atau menantikan sesuatu yang pasti terjadi namun tidak jelas kapan itu terjadi. Demikian juga gejala psikologi seperti kegelisahan, kehilangan kontrol diri, dan perasaan tidak nyaman, memiliki banyak sekali penyebabnya.

Selain pemahaman seperti dikemukakan di atas, ada juga pemahaman yang mengatakan bahwa stres itu lebih sebagai tekanan yang datang dari luar. Mereka beranggapan bahwa kejadiankejadian dari luar itu, seperti kebisingan suara, polusi udara dan air, kepadatan penduduk, bau tidak sedap, kehilangan kasih sayang, dan perubahan gaya hidup, bisa menyebabkan gangguan psikologis, fisik dan sosial., Stres disini adalah sesuatu yang berkaitan dengan kejadian-kejadian dari luar yang mempengaruhi munculnya respons dari manusia, baik yang muncul seketika maupun yang muncul dalam waktu yang agak lama kemudian. 
Sebagai tanggapan terhadap pandangan ini dapat dikemukakan bahwa berbagai stimulus seperti disebutkan di atas (umpamanya kebisingan) bisa saja sangat mengganggu dan bisa juga tidak, tergantung pada individu masing-masing orang yang menghadapinya, situasi dimana hal itu terjadi, kejadian lain yang muncul sebagai penyeimbang, serta imbalan atau biaya yang ditanggung terkait dengan kejadian-kejadian itu. Umpamanya saja, suara besar dari pembesar suara dapat dinikmati pada saat pesta, namun sangat mengganggu ketika kita sedang menyiapkan diri untuk menghadapi ujian. Begitu juga kepadatan atau kejarangan penduduk dapat menjadi tekanan atau malah menyenangkan tergantung pada jumlah kontak atau interaksi yang diinginkan.

\section{Stres sebagai Penyebab dan Akibat}

Mengikuti pembahasan sebelumnya, stres dapat dimengerti sebagai yang berkaitan dengan sesuatu yang terjadi (berarti dari luar, berupa stimulus) atau mengenai respons seseorang atas kejadian yang menghantuinya (dari dalam). Hal itu meliputi kejadian-kejadian lingkungan dan kejiwaan, interpretasi terhadap kejadian itu, serta perilaku yang kelihatan berupa respons fisik. Kebisingan lingkungan, umpamanya, bisa jadi berhubungan dengan perubahan yang terjadi pada fisik, kejiwaan dan perilaku yang dipicu oleh kebisingan tersebut. Sebaliknya, respons-respons tersebut dapat mengubah sesuatu dalam otak kita yang akhirnya mempegaruhi interpretasi kita terhadap kebisingan itu. Kebisingan itu mengubah aktivitas neural di bagian tertentu dalam otak kita, yang mana perubahan itu membawa perubahan pada pemahaman (interpretasi) kita terhadap kebisingan; sebaliknya perubahan pemahaman yang terjadi itu pada gilirannya mempengaruhi aktivitas neural dalam otak kita, dan demikian seterusnya. Oleh karena itu, stres sesungguhnya bukanlah stimulus dari luar, dan bukan juga respon dari dalam; dia adalah proses yang melibatkan keduanya, dan sebagai suatu proses, dia ikut mempengaruhi jalannya dimana kejadian-kejadian lingkungan dihadapi, dimaknai, direspon dan diubah (Veitch \& Arkkelin, 1995).

Walaupun usaha untuk merumuskan apa sebenarnya stress itu masih tetap berlangsung, yang jelas bahwa hal itu diakui adanya, dan bahwa hal itu melibatkan respon fisik, kejiwaan dan perilaku. Dalam perkembangannya stres itu juga memainkan peran besar mempengaruhi sistem kehidupan sosial manusia. Manusia-manusia yang mengahadpi tekanan dari luar, dengan berbagai respon yang diberikan terhadap stimulus itu, tidak lagi hanya terbatas dan berhenti pada individu-individu itu sendiri, melainkan membawa dampak pada hubungan antar individu, yang pada akhirnya menyentuh dan mempengaruhi suasana kehidupan sosial antar manusia. Menghadapi kejadian-kejadian lingkungan luar yang membawa ancaman, tantangan atau bahaya, manusia meresponnya secara fisik, kejiwaan dan perilaku. Respon-respon ini bukan hanya sangat membantu untuk menghadapi tuntutan dari perubahan lingkungan, melainkan bisa juga mengubah lingkungan itu sendiri, membutanya lebih ramah (walau tidak selalu tanpa disertai biaya atau pengorbanan).

Oleh karena itu Monat dan Lazarus (Veitch \& Arkkelin, 1995) memberi pengertian baru tentang stres sebagai suatu kejadian berupa tuntutan lingkungan dan/atau tuntutan internal (respons fisik dan kejiwaan) yang membebani atau melebihi kemampauan adaptif dari seseorang, mengganggu sistim jaringan dalam dirinya atau sistim sosial dimana dia menjadi bagian. Dengan pengertian ini, perubahan menjadi sangat menekan (stressfull) hanya ketika manusia memaksa sistem kemampuan menanggung beban yang dimilikinya untuk beradaptasi dengan perubahan itu. Dalam pengertian ini kedua aspek yang disebutkan sebelumnya, yakni stimulus (dari luar) dan respon (dari dalam), termasuk di dalamnya manusia sebagai partisipan aktif dalam proses itu, sudah tercakup atau mendapat tempat.

\section{Penilaian Terhadap Stress}

Persepsi seseorang terhadap lingkungan sebagai sumber dari stres akan menentukan responnya terhadap sumber stres (stressor) itu. Jika kita umpamanya percaya bahwa stressor tidak menyebabkan 
kerugian besar atau permanen kepada kita, maka respon kita tidak seekstrim ketika kita menganggap hal itu membawa kerugian besar dan berlangsung lama kepada kita. Begitu juga, jika sikap kita tampak setuju atau tidak peduli atas sesuatu hal yang berpotensi membahayakan, itu karena kita menilai bahaya itu sebagai kurang serius. Seseorang yang percaya bahwa dekat dengan rel kereta api adalah sebuah kesempatan yang bernilai ekonomis akan tidak terlalu peduli dengan kebisingan yang ditimbulkan oleh kereta api yang setiap saat lewat disitu. Ini tentu berbeda halnya dengan orang yang tidak memiliki persepsi seperti itu.

Umumnya ada tiga bentuk dasar penilaian yang dilakukan berkaitan dengan sesuatu yang berpotensi sebagai stressor. Pertama adalah Harm or loss assessments, yakni analisa terhadap kerusakan yang sudah terjadi. Ancaman yang terjadi dengan tiba-tiba, umpamanya gempa bumi, bisa mempengaruhi orang memberi penilain yang menakutkan disebabkan karena kerusakan besar yang diakibatkan oleh kejadian yang begitu cepat. Orang lebih perhatian pada akibat/konsekuesi besar dan mendadak itu. Yang kedua adalah Threat appraisal, yaitu analisa tentang bencana yang akan datang. Disini kejadian/bencana yang diyakini terjadi namun masih belum terjadi dapat dinilai sebagai yang lebih menimbulkan stress. Seperti halnya menantikan saat ujian tiba bisa lebih menegangkan ketimbang ketika ujian itu sedang berlangsung. Dan yang ketihga adalah Challenge appraisal, yakni analisa yang bukan berfokus pada kerusakan yang ada atau kemungkinan kerusakan dari suatu kejadian di masa depan, melainkan atas kemungkinan mengatasi stressor itu, sekurang-kurangnya meminimalisisr dampak kerusakannya. Ada memang stresssor yang berada di luar kemampuan manusia untuk mengatasinya, namun kita memiliki gambaran kejadian di dalam mana kita percaya akan kemampuan kita mengatasinya atau meminimalisir dampak negatif yang ditimbulkannya.

Suatu kejadian bisa saja kita anggap sebagai yang sangat membahayakan, akan tetapi kita bisa merasa bahwa kita punya cara untuk menghindari atau mengurangi dampak bahaya itu bagi kita. Seseorang bisa saja harus kehilangan pekerjaan karena harus pindah atau dipindahkan untuk menghindari suatu bencana, umpamanya. Stres dalam hal ini dapat dipandang sebagai ancaman (tentang bagaimana kita bisa menghindarinya, bagaimana kita bisa bertahan hidup), atau menganggapnya sebagai tantangan (tentang apa lagi yang kita lakukan untuk bisa tetap hidup dalam situasi itu, bagaimana kita bisa melakukan sesuatu yang terbaik dalam situasi buruk). Jadi, besarnya stressor, perkiraan kita tentang kemampuan kita mengatasinya, serta cara kita menghadapi permasalahan, semuanya ditentukan oleh bagaimana kita memandang kejadian itu apakah sebagai tantangan (challenging) atau ancaman (threatening). Banyak kenyataan memperlihatkan dimana suatu kejadian buruk yang dialami seseorang telah menjadi jalan untuk merubah nasibnya menjadi jauh lebih baik dari sebelumnya. Di tempat lain, dengan pekerjaan baru, dengan kesulitan baru dan dengan situasi yang serba baru, orang akhirnya merasa tertantang untuk berbuat sesuatu dengan cara yang lebih baik, sehingga hasilnya pun telah membawa perubahan besar dalam hidupnya dan/atau hidup komunitasnya.

\section{Hubungan Organisme-Lingkungan}

Stres dicirikan sebagai proses dimana kita sedang dalam situasi menghadapi stressor, menyadari bahayanya, dan menggerakkan usaha kita untuk mengatasinya. Intinya kita sedang dalam suasana harus frontal terhadap stressor, yang bisa sukses atau gagal beradaptasi dengannya. Umumnya proses itu berlangsung sebagai berikut: Ada hal yang membahayakan yang ditimbulkan oleh stressor, lalu manusia membuat penilaian terhadap stressor itu, memilih strategi yang digunakan untuk menanggulanginya, kemudian manusia beraksi memobilisasi diri, baik secara fisik maupun kejiwaan untuk melawan stressor. Jika cara yang dilakukan berhasil, adaptasi dicapai, dan dampak dari stress berkurang. Jika penanggulangan tidak berhasil, stres tetap ada, ketegangan kejiwaan dan pengaruhnya pada fisik tidak berkurang, dan bahkan bisa mengakibatkan dampak yang lebih parah, seperti terjadinya psychological disorder (Veitch \& Arkkelin, 1995). 
Kadang ada saatnya dimana organisme hidup berada dalam keseimbangan dengan alam lingkungan sekitarnya, sehingga tidak ada yang membuat tekanan. Dan ada juga saatnya dimana hubungan ini terganggu. Maka stress dapat juga dimengerti sebagai ketidakseimbangan (disequilibrium) antara organisme hidup dengan lingkungan sekitarnya. Ada saatnya dimana di satu pihak lingkungan memberikan tantangan yang begitu berat, sementara di pihak lain manusia telah kehilangan kemampuan menangulangi, atau gagal beradaptasi. Bisa juga kedua kondisi itu yang terjadi bersamaan. Tentu mudah untuk membayangkan bagaimana keadaannya bila kedua kemungkinan itu yang terjadi, dipastikan hubungan keseimbangan itu sudah sangat terganggu. Dan kalau kita melihat keadaan yang terjadi sekarang ini hubungan tersebut sedang dalam keadaan "disequilibrium". Ghina (2003) mengungkapkan beberapa hal yang perlu mendapat perhatian serius manusia zaman ini yakni perubahan suhu bumi dan naiknya debit air laut, ancaman terhadap keberagaman hayati, ancaman ketidaktersediaan air bersih, kerusakan daerah pesisir pantai, polusi, energi dan turisme.

Hal yang dapat dikemukakan juga disini adalah bahwa ketidakseimbangan ini terjadi tergantung pada jumlah proses-proses fisik dan kejiwaan. Sebagai contohnya, seberapa jauh suatu bunyi dalam kondisi tertentu dapat dianggap sebagai kebisingan, dan sejauhmana anggapan ini mempengaruhi respon fisik dan kejiwaan terhadap sumber kebisingan itu. Berbagai unsur dari lingkungan seperti kondisi udara, kepadatan penduduk, perkembangan teknologi dengan berbagai hal yang dihasilkannya, dan sebaginya, semuanya memiliki potensi untuk menimbulkan stres. Di pihak lain kitapun berusaha untuk menggambarkan keadaan ketika hal itu terjadi, mencoba menggambarkan seberapa besar dampaknya bagi kita dan kehidupan pada umumnya. Akhirnya kita masih berusaha memikirkan cara mengatasinya, baik stres itu sendiri maupun dampaknya yang merugikan.

\section{Sikap Menghadapi Stress}

Respon terhadap stressor berkaitan dengan bagaimana stressor itu dipahami. Sikap kita terhadap sumber stres itu adalah faktor penting kejiiwaan yang bertindak sebagai alat bagi pemahaman atas stressor. Sebagai contoh, untuk suatu hal, tidak selalu sama penilaian yang diberikan oleh kelompok dengan yang dberikan oleh individu yang ada dalam kelompok itu. Bisa saja suatu kelompok menyampaikan keberatan untuk sesuatu hal, tapi individu-individu yang ada dalam kelompok bisa memiliki pemahaman dan penilaian yang berbeda. Umum terjadi bahwa penilaian dan sikap yang muncul terhadap suatu realitas banyak juga dipengaruhi oleh budaya dimana seseorang hidup dan dibesarkan (Horowitz, 2008). Namun lepas dari situ, penilaian-penilian itu berkaitan banyak dengan cost dan benefit yang didapatkan. Rencana pembangunan reaktor nuklir di suatu tempat, pasti ada yang mendukung dan ada juga yang menolak. Disini orang semacam melakukan threat appraisal, mencoba mengkaji kejadian yang akan datang berkaitan dengan beroperasinya reaktor nuklir tersebut. Evaluasi yang diberikan merupakan fungsi keseimbangan antara benefit dan cost yang diterima atau ditanggung.

Terkait dengan sikap yang dibangun menghadapi sumber stres, ada 4 hal penting yang dapat dilakukan, dengan manfaat penting yang sangat membantu.

\section{Control}

Kemampuan melakukan kontrol merupakan suatu mediator atau aktivitas kejiwaan yang sangat kuat terhadap stres. Dia menyediakan perasaan mampu mengahadapi masalah secara efektif, mampu memprediksi suatu kejadian, serta dapat mengetahui konsekuensi dari sesuatu sebelum hal itu terjadi. Glass dan Singer mengklaim bahwa dampak dari suatu kejadian yang sebelumnya dapat diprediksi dan dikontrol akan lebih murah biaya adaptasi terhadapnya Sementara Tursky dan Schwartz mengatakan bahwa orang yang memiliki kontrol atas suatu goncangan (shock) akan mengalami ketidaknyamanan yang sedikit dibandingkan dengan seseorang yang tidak memiliki kontrol atas intensitas dari goncangan itu (Veitch \& Arkkelin, 1995). 
Disini menjadi jelas bahwa kontrol itu mempengaruhi penilaian kita atas stressor. Dengan banyaknya informasi yang kita dapatkan sebelumnya terkait suatu kejadian, kita bisa lebih mudah melakukan antisipasi dan adaptasi terhadapnya dengan biaya yang lebih murah dibandingkan kalau kita tidak memiliki informasi sama sekali serta tidak melakukan sesuatu untuk menghadapinya. Jadi, hasil yang didapat dari adanya kontrol ini adalah akibat atau dampak dari suatu kejadian (stressor) dapat dikurangi dengan cara adanya penilaian yang baik berupa pemetaan atau perkiraan yang agak komprehensif atas sesuatu yang bakal terjadi dan / atau dengan mengembangkan kemampuan yang dimiliki untuk mangatasinya. Ujung dari proses ini adalah stres menurun.

\section{The Hardy Personality}

Ini adalah sesuatu yang berkaitan tentang sejauhmana kondisi seseorang kuat terhadap tekanan. Ini pertama berkaitan dengan ketahanan fisik seseorang. Orang yang sering berlatih secara fisik (seperti olah raga), dia akan memiliki fisik yang lebih sehat, dan tidak mudah jatuh sakit. Seoranmg individu yang secara fisik lebih sehat dan kuat akan terpengaruh lebih sedikit dalam hal dampat fisik ketika menghadapi stres.

Keadaan fisik yang kuat dan sehat akan mempengaruhi juga kondisi kejiwaaan, karena dia bisa memaknai suatu yang memberatkan sebagai tantangan dan bahkan kesempatan, dan dia percaya bahwa dia bisa mengontrol hidupnya dalam berhadapan dengan stres itu. Faktor kemampauan fisik seperti ini oleh Kobasa telah diberi nama sebagai hardiness, dan berhubungan dengan yang Zimmerman sebut sebagai learned hopefulness, yakni tahu bagaimana mengatasi masalah, yang didukung oleh adanya sense of control. Di bagian lain Contrada telah memperlihatkan bahwa pribadi yang disebut hardy cenderung tidak dibanjiri oleh situasi sulit, mereka gencar mencari solusi, dan menjadi lebih konstruktif. Sebagai hasilnya, mereka kurang mengalami stres, tidak mudah sakit, dan tekanan darah lebih normal. Hal sebaliknya dengan pribadi yang kurang hardy, mereka adalah indivu yang pessimis, mengalami banyak gejala penyakit, dan mengalami banyak kejadian-kejadian yang stressful, dan bahkan meninggal pada umur yang masih muda (Veitch \& Arkkelin, 1995).

\section{Social Support}

Seperti kita ketahui bahwa dukungan dan bantuan sosial itu sangat diperlukan dalam kehidupan bersama, khususnya ketika sedang menghadapi bencana seperti gempa bumi atau bencara teknologi, seperti kebocoran pembangkit tenaga nuklir. Jaringan dukungan sosial dapat diharapkan untuk meringankan beban tekanan dari kejadian-kejadian lingkungan yang memberatkan. Kerusakan yang diakibatkan oleh banjir besar, atau gempa dan/atau tsunami, biasanya menyisakan kondisi lingkungan yang sangat memberatkan, selain korban jiwa dan harta benda. Dengan kerjasama masyarakat membersihkan sisa-sisa kerusakan itu, maka kondisi yang menyebabkan stres itu bisa cepat dihilangkan, dan pekerjaan itu pun menjadi ringan karena dikerjakan oleh banyak orang. Hubungan jaringan sosial ini bisa berlangsung dalam dua sisi, pertama: orang yang memiliki dukungan sosial umumnya lebih sehat, dan kedua, ketika mereka dihadapkan pada kejadian yang menekan, orang lain yang berada dalam jaringan sosial itu dapat bertindak sebagai penyangga, yang menyediakan hal-hal yang meringankan, menguatkan hati, dan jika perlu, menyumbang darah dan makanan. Lebih dari itu hubungan interpersonal yang baik menyediakan kesempatan untuk saling bebagi (terbuka), mengungkapkan perasaan. Semuanya itu membuat seseorang bisa lebih efektif dalam mengatasi masalah yang menekannya.

\section{The Relaxation Response}

Selain respopns terhadap stressor yang sudah disebutkan sebelumnya ada sebuah kenyataan lain yang berkembang yang dapat disebut respon anti stres, yaitu suatu respon relaksasi (Veitch \& Arkkelin, 1995). Benson menemukna bahwa dalam respon ini ketegangan otot menurun, aktivitas 
lapisan otak menurun, denyut jantung dan tekanan darah menurun, serta nafas jadi pelan. Menurut Benson, stimulus yang dibutuhkan untuk memproduksi respon ini, di antaranya adalah lingkungan sekitar yang hening, mata terpejam, posisi badan menyenangkan (enak), serta pemusatan perhatian pada suatu hal tertentu. Kondisi ini memungkinkan badan mencapai level lebih rendah perihal mudahnya kena pengaruh dari luar, dan cepat pulih/sembuh dari keadaan tertekan. Benson mengingatatkan bahwa faktor keempat ini ditemukan dalam banyak tradisi dan agama-agama berupa teknik-teknik meditasi dan doa, dan kemudian dikembangkan dalam kegiatan-kegiatan spiritual, yang umunya menghasilkan penyembuhan dari keadaan yang memberatkan.

\section{Antisipasi yang Lebih Baik}

Hal-hal yang berpotensi menimbulkan stres bagi manusia yang berasal dari lingkungan memang ada yang berada di luar jangkauan manusia untuk mengontrol atau mencegah agar tidak terjadi. Gempa bumi, tornado, letusan gunung berapi dan sebagainya, termasuk di antara kejadiankejadian yang dimaksud. Namun ada juga hal-hal yang berpotensi menyebabkan stres yang ditimbulkan oleh lingkungan yang sebenarnya berada di bawah kendali manusia. Ada berbagai kondisi alam lingkungan yang mengancam kehidupan manusia yang disebabkan oleh eksploitasi berlebihan dari manusia itu sendiri. Banjir, tanah longsor, polusi udara dan air, pemanasan global dan lain-lain merupakan kejadian-kejadian dimana manusia punya andil di dalamnya, yang mendorong hal-hal itu terjadi. Berbagai dampak negatif yang timbul dari kemajuan ilmu dan teknologi jelas-jelas merupakan buah dan sisi lain dari kemajuan peradaban manusia. Umpamanya saja berbagai alat trasportasi hasil ciptaan manusia seperti mobil, sepeda motor, dan lain-lain, yang diproduksi dalam jumlah yang semakin banyak, selain membawa manfaat besar juga telah menjadi sumber stres bagi manusia sendiri. Kendaraan yang sudah semakin banyak itu telah menimbulkan persoalan baru, seperti kemacetan, polusi, kebisingan, dsb.

Sadar akan hal ini, manusia ditantang untuk lebih peduli pada potensi timbulnya stres dari tindakan dan hasil karyanya sendiri. Cara memandang dan memperlakukan alam mesti berubah. Dari sikap mau menguasaai alam, mengeksploitasinya secara berlebihan, harus berubah menjadi sikap menyayangi alam, bahkan menyayanginya bagai menyayangi diri sendiri. Harus ada komitmen tinggi untuk tidak merusak alam, karena sadar bahwa melukai alam sama dengan melukai diri sendiri. Tindakan manusia merusak alam lingkungannnya sama dengan tindakan membunuh dirinya sendiri secara pelan-pelan. Perubahan sikap dalam memandang dan memperlakukan alam dengan baik, memelihara dan melestarikannya, bukan saja bahwa alam terhindar dari kerusakan, yang pada gilirannya membawa bencana bagi manusia. Tindakan itu sekaligus juga mengkondisikan alam secara positif, untuk terus mampu menyediakan berbagai hal penting yang dibutuhkan oleh manusia, baik manusia di zaman sekarang maupun manusia generasi yang akan datang.

\section{Acuan Tanggungjawab dalam Memperlakukan Alam}

Ada dua hal penting yang dapat dijadikan acuan dalam hal memandang dan memperlakukan alam, yakni keutuhan biosfir dan keselamatan generasi yang akan datang (Gea \& Wulandari, 2006). Bumi sebagai satu kesatuan ekosistem mengandung di dalamnya berbagai lapisan kehidupan, yang dalam keberlangsungannya saling terkait satu sama lain. Keseluruhan hubungan saling terkait itu disebut dengan istilah biosfer. Dimensi saling terkait dan saling ketergantungan satu sama lain itu merupakan kekhasan keberadaan tiap kenyataan di bumi ini. Ada hubungan yang berlangsung terus menerus antara manusia, makhluk hidup dan segala unsur yang ada dalam alam semesta. Namun dari semua lapisan itu manusia memiliki peranan penting. Manusia adalah agen perubahan, yang memiliki kemampuan untuk menciptakan perubahan di bumi ini. Manusia dapat menggali tanah untuk menemukan air, membelokkan sungai dan mengalirkan air ke gurun dan mendirikan kota di atasnya, membuat jalan dan membangun istana di tengah hutan, mengolah bahan-bahan kimia dan memanfaat 
kan energi demi berbagai keperluan. Di tangan manusia bumi mengalami transformasi besar (Postel, 1994).

Dalam lapisan-lapisan kehidupan di bumi ini, manusia hanyalah merupakan salah satu lapisan di antaranya, yang memiliki hubungan saling ketergantungan dengan lapisan kehidupan lainnya. Maka kalau ada kerusakan yang dialami oleh suatu lapisan kehidupan, baik di darat (di daratan rendah, di daratan tinggi, di dalam tanah), di laut (di permukaan, di tengah dan di dasar laut) dan di udara, cepat atau lama pasti akan mempengaruhi kehidupan manusia juga. Dalam salah satu teori tentang lingkungan, yakni ekosentrisme, yang kemudian dikenal sebagai deep ecology, dikemukakan bahwa manusia bukanlah penguasa dan bukan pula pusat alam semesta. Manusia dipandang sebagai salah satu makhluk ciptaan Tuhan, yang tidak berhak mengancam dan meniadakan keberadaan ciptaan lain (Gea \& Wulandari, 2006). Dengan mengakui semua makhluk sebagai ciptaan Tuhan, maka kita juga akan mengakui adanya hak setiap makhluk untuk diperlakukan dengan baik. Pemahaman seperti ini akan mendorong tumbuhnya sikap etis manusia dalam memperlakukan semua ciptaan Tuhan (Galli, 2011).

Teori ekosentrisme merupakan teori yang pantas didukung karena melawan terori antroposentrisme yang dianggap sumber kekeliruan dalam memandang dan memperlakukan alam, yang mengedepankan penggunaan teknologi yang semakin canggih untuk menguras isi bumi dan menguasasinya. Kita sadar betul bahwa kita bergantung pada lingkungan (alam) dan bukan sebaliknya, lingkungan bergantung pada kita. Kalau kita mati, alam tetap ada, sedangkan kalau alam rusak, kita pasti musnah. Maka kalau kita ingin hidup dengan baik, mau tidak mau kita harus merubah sikap dalam memandang dan memperlakukan alam. Pilihan ini bukan saja hanya supaya kita terhindar dari ancaman oleh alam, melainkan lebih dari itu, alam juga, sebagai ciptaan Tuhan, memiliki hak untuk tidak dirusak, terutama oleh egoisme manusia sendiri. Graig (2011) menyatakan bahwa manusia dan segala ciptaan lainnya, baik yang biotik maupun yang abiotik, memiliki daya hidup (spirit) yang hadir bersama dengan kehadiran fisik mereka di alam ini.

Apa yang dilakukan manusia sekarang ini pengaruhnya bukan hanya dirasakan oleh manusia zaman sekarang melainkan lebih besar lagi dirasakan oleh generaasi yang akan datang. Dan kita sebagai manusia, bersama dengan generasi yang akan datang, memiliki hak dan kewajiban yang sama untuk menikmati lingkungan hidup yang indah, lestari dan berdaya hidup. Dengan mengeksploitasi alam secara tak terkendali berarti kita telah merampas apa yang menjadi hak generasi yang akan datang. Dan itu adalah salah satu kesalahan moral serius yang pernah kita lakukan dalam hidup ini. Sadar akan hal tersebut maka kita manusia zaman sekarang memiliki tanggung jawab moral yang besar untuk memelihata alam ini dengan baik, dan mewariskanya kepada generasi yang akan datang dalam keadaan baik. Dalam kaitan dengan bisnis modern Gifford (1992) menyatakan bahwa untuk menjadi sukses dalam era baru lingkungan hidup sekarang ini, para eksekutif di berbagai institusi harus lebih bijak dalam mengambil keputusan dan tindakan mengingat dampak yang besar dari setiap kebijakan yang mereka ambil terhadap lingkungan hidup. Ini sejalan dengan ecosophy (istilah yang digunakan oleh Arne Naes) sebagai landasan filosofis dari pandangan deep ecology, yang berarti suatu kearifan mengatur hidup selaras dengan alam sebagai sebuah rumah tangga dalam arti luas (Gea \& Wulandari, 2006)

\section{Acuan Tanggung Jawab dalam Pengembangan dan Pemanfaatan Teknologi}

Teknologi sebagai perpanjangan anggota tubuh manusia, yang membuatnya mampu melakukan banyak hal dan dengan jumlah yang banyak, selain mendatangkan banyak manfaat besar, juga telah membawa serta masalah dalam kehidupan manusia, yang berkaitan dengan proses timbulnya strres. Dampak-dampak negatif dari teknologi telah membawa berbagai masalah baru bagi manusia. Dampak-dampak itu bahkan sampai pada wilayah yang paling serius, seperti rekayasa genetik, yang 
telah menjadikan manusia sebagai obyek dan alat penelitian, yang telah menempatkan manusia pada kondisi keterancaman martabat yang serius.

Para ilmuwan harus memikul tanggung besar dalam pilihan dan pengembangan teknologi. Tidak hanya memperhatikan kecanggihan dengan hasil-hasil positif yang didapatkan, melainkan juga sisi-sisi negatif yang berpotensi mengancam kenyaman dan keselamatan kehidupan. Suara bising yang memekakkan telinga dari pesawat terbang umpamanya perlu dicari cara menguranginya, tentang bagaimana meredam suara gesekan udara pada sayap dan badan pesawat. Kendaraan yang diproduksi semakin banyak perlu di cari jalan bagaimana agar tidak mengakibatkan masalah serius bagi pengguna jalan. Perlu dipikirkan berbagai alternatif agar perjalanan bisa tetap lancar, tidak menimbulkan kemacetan yang parah setiap hari. Emisi gas yang dikeluarkan dari berbagai pembuangan juga perlu dipelajari bagaimana cara mengurangi konsentrasinya di udara, yang mengancan kesehatan dan berdampak pada proses timbulnya stres. Ini hanya contoh kecil saja. Ada banyak contoh bisa disebutkan yang intinya adalah bagaimana agar teknologi itu, yang tentu tidak mungkin dihentikan perkembangannya, tidak membuat kehidupan malah semakin terancam, dan membuat keseimbangan hubungan manusia dengan alam lingkungannya menjadi sangat terganggu.

Hal lain dapat disebutkan disini, dalam pemilihan teknologi umpamanya perlu pilihan lebih banyak pada teknologi adaptif dan protektif. Adaptif artinya dapat doperasikan oleh mayoritas masyarakat, bahkan sampai ke pedesaan. Teknologi ini bisa membantu para pekerja di pertanian, peternakan, perkebunan, perikanan dan kerajinan tangan, untuk meningkatkan produktivitas mereka, namun dengan biaya yang lebih murah. Selain adaptif perlu juga diperhatikan sisi protektifnya, yakni teknologi yang diproduksi dan digunakan lebih ramah lingkungan, tidak membawa dampat merusak pada lingkungan sekitar. Kita perlu melihat kembali hubungan antara peradaban (kemajuan) dengan alam lingkungan hidup.

\section{PENUTUP}

Dari Manusia hidup dan berkembang di tengah-tengah lingkungan yang semakin kompleks. Manusia setiap saat berhadapan dengan suasana yang menuntutnya beradaptasi secara baik dalam arti bisa menyelaraskan hidupnya dengan lingkungan dimana dia berada. Walaupun manusia memiliki kemampuan adaptasi yang tinggi, namun dalam kenyataannya manusia sering merasa terbebani oleh keadaan lingkungannnya yang berubah cepat dan sering tidak bersahabat. Kondisi seperti ini telah menjadi masalah tersendiri bagi manusia. Berbagai kejadian di lingkungan sekitar telah menjadi sumber stres bagi manusia, yang berdampak pada fisik, jiwa dan perilakunya, dan merambas juga ke wilayah sosial yang lebih luas. Stres yang timbul disini bisa dimengerti sebagai tekanan dari lingkungan berupa kondisi atau kejadian yang memberatkan bagi kemampuan adaptasi manusia, dan bisa juga dimengerti sebagai respon yang berasal dari manusia sebagai reaksi atas kejadian yang terjadi di luar dirinya. Kita tidak harus memilih mana di antara kedua pengertian itu yang kita yang kita pegang. Yang penting proses terjadinya stres melibatkan kedua hal itu, unsur dari luar dan dari dalam diri manusia. Stres timbul sebagai indikasi terjadinya kegagalan adaptasi, yang disebabkan baik oleh beratnya tekanan lingkungan berupa kejadian-kejadian yang mengancam maupun kemanpuan manusia yang terbatas untuk memberi respon yang baik dan konstruktif.

Berbagai kejadian di luar diri manusia yang membawa ancaman bagi kehidupannya ada yang di luar kendali manusia namun ada juga yang ikut disebabkan oleh tindakam manusia itu sendiri, khususnya yang berkaitan dengan kemajuan ilmu pengetahuan dan teknologi yang dihasilkannya. Berbagai produk teknologi ciptaan manusia selain membawa manfaat besar bagi manusia juga telah mendatangkan berbagai ancaman bagi dirinya. Polusi udara dan air, kebisingan, banjir, kemacetan lalulintas, dsb, merupakan kejadian-kejadian yang memicu terjadinya stres. Keinginan manusia untuk 
mengolah alam sesuai dengan kebutuhan dan keinginannya, menciptakan berbagai peralatan teknologi untuk memperpanjang kemampuan anggota tubuhnya, ternyata telah menjadi suatu sumber terjadinya masalah bagi manusia sendiri.

Menghadapi berbagai tekanan yang berasal dari lingkungan, baik yang ditimbulkan oleh bencana alam maupun yang disebabkan oleh tindakan manusia sendiri, perlu mengembangkan sikap yang tepat, baik berupa cara menghadapi kejadian itu sendiri maupun antisipasi untuk meminimalisir atau menncegahnya bila memungkinkan. Hal yang perlu dimiliki juga adalah kemampuan untuk menilai dengan baik suatu kejadian, karena hal itu sangat berpengaruh pada sikap dan perilaku serta respon yang diberikan kemudian. Demikian juga kemampuan adaptasi perlu ditingkatkan, termasuk kemampuan memandang dan menyikapi kejadian sebagai ancaman atau tantangan. Banyak terjadi dimana sikap memandang kejadian sebagai tantangan telah membawa hal yang positif dan luar biasa besar bagi seseorang, walaupun pada tahap awal ada cost yang harus dibayar untuk itu, seperti pindah tempat tinggal, hilang pekerjaan, bahkan kehilangan kasih sayang.

\section{DAFTAR PUSTAKA}

Galli, C. D. (2011). Enoch's Vision and Gaia: An LDS Perspective on Environmental Stewardship. Dialogue : A Journal of Mormon Thought. 44 (2), 36-57.

Gea, A. A., \& Wulandari, A. P. Y. (2006). Character Building IV, Relasi dengan Dunia. Jakarta: Elex Media Komputindo.

Ghina, F. (2003). Sustainable Development in Small Developing States. Environment, Development and Sustainability; 5, 1-2; ABI/INFORM Global, pp. 139-165

Gifford, P. (1992). The Ecology of Success. Executive Excellence; 9, 10; ABI/INFORM Global, pp. 78

Horowitz, L., S. (2008). Destroying God's Creation or Using What He Provided?: Cultural Models of a Mining Project in New Caledonia. Human Organization; 67, 3; ABI/INFORM Clobal, pp. 292-304

Postel, S. (1994). Carrying capacity: Earth’s bottom line. Challenge; 37, 2; ABI/INFORM Global, pp. 4-12.

Raven, P. (1995). A Time of catastrophic extinction - What we must do. The Futurist; 29, 5; ABI/INFORM Global, pp. 38-41.

Veitch, R., \& Arkkelin, D. (1995). Environmental Psychology. An Interdisciplinary Prospective., Englewood Cliffs. New Jersey: Prentice-Hall. 